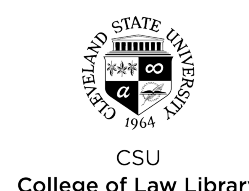

Cleveland State University

College of Law Library

\title{
EngagedScholarship@CSU
}

Fall 2014

\section{FTC v. Lundbeck: Is Anything in Antitrust Obvious, Like, Ever?}

\author{
Chris Sagers \\ Cleveland-Marshall College of Law, Cleveland State University, c.sagers@csuohio.edu
}

Richard M. Brunell

American Antitrust Institute, rbrunell@antitrustinstitute.org

Follow this and additional works at: https://engagedscholarship.csuohio.edu/fac_articles

Part of the Antitrust and Trade Regulation Commons

How does access to this work benefit you? Let us know!

\section{Repository Citation}

Sagers, Chris and Brunell, Richard M., "FTC v. Lundbeck. Is Anything in Antitrust Obvious, Like, Ever?" (2014). Law Faculty Articles and Essays. 796.

https://engagedscholarship.csuohio.edu/fac_articles/796

This Article is brought to you for free and open access by the Faculty Scholarship at EngagedScholarship@CSU. It has been accepted for inclusion in Law Faculty Articles and Essays by an authorized administrator of EngagedScholarship@CSU. For more information, please contact research.services@law.csuohio.edu. 


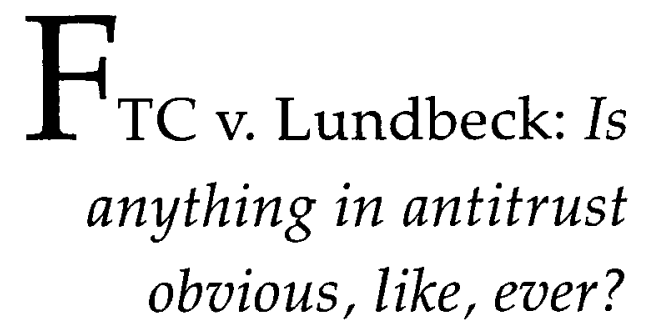

By CHRIS SAgERS* AND RichaRd M. BRUNELL **

In FTC $v$. Lundbeck, the Eighth Circuit affirmed a bench verdict finding a merger to monopoly, followed by a $1400 \%$ price increase, not only legal, but effectively not even subject to antitrust. The result followed from the district court's view that peculiarities in the market for hospital-administered drugs rendered it essentially immune from price competition. That being the case, the court found that even products very plainly substitutable on any traditional "functional interchangeability" analysis are not in the same "relevant market" for purposes of rules governing horizontal mergers. We think the court's analysis was incorrect for a number of factual reasons, but stress that, much more importantly, a case like Lundbeck calls for return to traditionally broad, prophylactic rules.

KEY WORDS: Lundbeck, merger, pharmaceuticals, market definition

* James A. Thomas Distinguished Professor of Law, Cleveland State University, and Senior Fellow, American Antitrust Institute.

** General Counsel, American Antitrust Institute.

AUTHORS' NOTE: We submitted a brief amicus curiae in the Eighth Circuit in Lundbeck on behalf of the American Antitrust Institute, urging reversal in favor of plaintiff Federal Trade Commission. The views expressed here are our own and do not represent the views of the American Antitrust Institute.

(C) 2014 by Federal Legal Publications, Inc. 


\section{INTRODUCTION}

Entia non sunt multiplicanda praeter necessitatem. -Commonly attributed to William of Ockham ${ }^{1}$

Just how elaborate or counterintuitive must one's defense of seemingly anticonsumer conduct become before its complexity suggests that one is on the wrong track?

Many people thought things like that about Federal Trade Commission v. Lundbeck, Inc., ${ }^{2}$ a 2010 consummated merger challenge that the Federal Trade Commission (the FTC or the Commission) lost on bench verdict and failed to overturn before the Eighth Circuit. Surely the Commission asked such questions. The deal-which combined Indocin IV and NeoProfen, the only two drugs to treat a potentially life threatening condition in infants-was a merger to monopoly over a product with a highly inelastic demand, and the merger was followed by price increases of nearly $1400 \% .{ }^{3}$ One rather suspects John Sherman had such cases in mind. And so, among lawyers, journalists, and other observers, there was some serious head-scratching when the Commission not only failed to get the unequivocally slam-dunk win that many thought it had coming, but lost. ${ }^{4}$

1 See William of Ockham, in Stanford EnCyClopedia of Philosorhy ("entities must not be multiplied beyond necessity"), available at http:/ / plato .stanford.edu/entries/ockham/.

2 FTC v. Lundbeck, Inc., No. 08-6379, 2010 WL 3810015 (D. Minn. Aug. 31, 2010), aff'd, 650 F.3d 1236 (8th Cir. 2011).

3 The Chairman made a minor cause célébre of these dramatic facts. See, e.g., Concurring Statement of Commissioner Leibowitz, FTC v. Ovation Pharmaceuticals, Inc., No. 0810156 (Dec. 16, 2008), available at http://www.ftc.gov/sites / default / files / documents / cases / 2008/12/081216ovationleibowitzstmt.pdf. ("Ovation's profiteering on the backs of critically ill premature babies is not only immoral, it is illegal. Ovation's behavior is a stark reminder of why America desperately needs health care reform and why vigorous antitrust enforcement is as relevant today as it was when the agency was created almost one hundred years ago in 1914.").

${ }^{4}$ See Jenna Greene, FTC Loses an Easy One, NAT'L L.J., Sept. 27, 2010. See also Herbert Hovenkamp, Mergers With Dominant Firms: The Lundbeck Case, COMPEIITION POL'Y INT'L, Dec. 13, 2011; Steven C. Salop, Merger Settlement and Enforcement Policy for Optimal Deterrence and Maximum Welfare, 81 FordHAM L. REv. 2647, 2664 n.48 (2013) (Lundbeck was an "inexplicable market definition error."). 
In the end, this case was fairly bizarre all around and not just because seemingly drastic antisocial conduct went unremedied. However, while we definitely will spend some time considering the facts and legal specifics, we want to say up front that to us further bickering over details is not what really matters. Most important to us, Lundbeck is the kind of case showing why antitrust sometimes needs simple rules. It shows why antitrust ordinarily reserves a rule of effectively per se illegality for monopoly-preserving mergers ${ }^{5}$ and why such a rule should have been followed.

But, given the symposium topic, we'll also suggest some more technical reasons why the approach to market definition in Lundbeck was so bad. For one thing, to an overwhelming new degree, the court put the market definition cart before the horse of any actual policy goal. It had been a consensus in antitrust that market definition is not an end in itself, but only one means to identify situations of potentially harmful conduct. ${ }^{6}$

For another thing, in purporting to define this market, the court appeared to apply rules of law that we thought were radical and dangerous. Clearly implied by the court was the view that if a market seems like it already lacks price competitiveness, then a plaintiff cannot show relevant injury. The court believed that because of institutional peculiarities affecting the market for hospital-administered drugs, the degree of

5 See 3 Phillip E. AREeda \& Herbert Hovenkamp, Antitrust law 17 701d (3d ed. 2008) (monopolist's "acquisition of any firm that has the economic capabilities for entry and is a more-than-fanciful possible entrant is presumptively anticompetitive"); United States v. Grinnell Corp., 384 U.S. 563, 576 (1966) (monopolist's acquisition was illegal where it "eliminated any possibility of an outbreak of competition that might have occurred").

6 See United States v. Cont'l Can Co., 378 U.S. 441, 453 (1964) ( "Interchangeability of use and cross-elasticity of demand are not to be used to obscure competition but to 'recognize competition where, in fact, competition exists.'" (quoting Brown Shoe Co. v. United States, 370 U.S. 294, 326 (1962))); United States v. Archer-Daniels-Midland Co., 866 F.2d 242, 246 (8th Cir. 1988) (same); U.S. DeP'T OF Justice AND FTC, HorizonTAl MERGer GuIdelines § 4 (2010) [hereinafter 2010 HorIzONTAL MERGER GUIDELINES] (market definition "is not an end in itself, but is useful to the extent it illuminates the merger's likely competitive effects"); cf. Louis Kaplow, Why (Ever) Define Markets?, 124 HARV. L. REV. 437, 443 (2010). 
price constraint that even closely substitutable drugs can impose on each other is muted. Only implicit was its corollary view that if the acquisition did not alter prices, then it did no harm. Implicitly, then, the court seemed to hold that if a market seems to be already uncompetitive, then antitrust law does not apply to it. We think that is unprecedented and contrary to existing policy. The court also seemed to imply, contrary to black letter law, that quality competition is irrelevant in antitrust. And finally, the court was just dead wrong that there was no substitutability based on price. Its own findings elaborately demonstrate it.

Admittedly, Lundbeck is really just one unpublished trial court decision, affirmed only on standard of review grounds, and it was widely thought to be incorrect. But we think it matters. Litigated merger cases are so rare that they all matter. Moreover, the narrow facts of Lundbeck will recur. Lundbeck actually acquired the drugs through its predecessor, Ovation Pharmaceuticals, a firm that can be likened not unfairly to a patent troll. There just happens to be another such firm trying to pull off a similar deal at the moment (involving a $56,000 \%$ price increase),

7 Ovation developed no drugs of its own. It was a private equity vehicle designed to acquire underpriced drugs, which it then produced through agreements with other manufacturers. See GTCR LLC, Ovation Pharmaceuticals: Finding Healthy Profits in Health Care, http://www.gtcr.com/ourfocus/healthcare / leadership-stories / ovation-pharmaceuticals-inc/ (last visited Apr. 28, 2014).

8 A U.S. firm called Questcor exists solely to own one drug, Synacthen, which it did not develop and which is the only approved drug of its kind in the United States. Since acquiring it in 2001, Questcor increased its price from $\$ 40$ to $\$ 28,000$. In mid-2013, Questcor acquired a second drug that is not yet approved in the United States, but is indicated for the same uses overseas. A separate rival to purchase that drug has sued Questcor, claiming it would have sold Synacthen in the United States for "a few hundred dollars a vial," see Complaint, Retrophin, Inc. v. Questcor Pharms., Inc., No. 8:14-CV-00026JLS-JPR (N.D. Cal. Jan. 17, 2014), and market analysts report that the FTC is investigating as well. See Questcor/Synacthen: Antitrust, Political Analysis Reveals Significant Risk That FTC Will Investigate U.S. Patent Rights Acquisition; Likelihood of Challenge to Turn on Competitive Landscape of Long Release ACTH Drugs, CAPITOL ForuM, Aug. 1, 2013. See also Letter from Amy Klobuchar, U.S. Senate, to Edith Ramirez, Chair, Federal Trade Commission (Aug. 1, 2013), available at http:/ / www.citronresearch.com/wp-content/uploads / 2013/12 /QCOR-Sen-Klobuchar-Letter-to-FTC-8-1-2013.pdf; Citron Research, Questcor (NASD:QCOR): A Single Digit Stock in 18 Months or Less, and Here's Why July 
and who knows how many others there may be. The court's reasoning also poses some broad competitive risks in the pharmaceutical sector. Hospital-administered drugs are apparently all or mostly purchased in the same way, so it is not clear why any would be subject to Clayton Act section 7. That seems pretty radical. And finally, the even bigger and grimmer reason to care about a case like Lundbeck is what it says about the state of antitrust generally. That a court (and commentators ${ }^{9}$ ) could look at a monopolist's acquisition of its only rival, in a deal delivering no social benefit whatsoever, and hold not only that it is not illegal, but not even subject to antitrust, suggests that many courts can no longer imagine an antitrust defendant ever losing.

We begin with a brief recounting of the facts, emphasizing those that made Lundbeck seem easy to us. We then discuss two particular problems in the court's market definition that we think were mistaken-the apparent view that quality competition is irrelevant, and the disregard for evidence of actual price competition. But we conclude with a point that, again, really ought to trump any further nitpicking over facts or economic theory. Even if there might be some conceivable model under which this acquisition didn't make anything any worse, we have to ask: Why shouldn't a monopolist's acquisition of its next closest competitor, not even arguably producing any social benefit, just be illegal, period?

\section{THE FACTS, AS THEY LOOKED TO US}

Indocin IV and NeoProfen-the drugs in question-are not identi$\mathrm{cal}^{10}{ }^{10}$ but they are the only FDA-approved drug remedies for a heart condition in premature infants known as patent ductus arteriosus

10,2011 ) (setting out rather striking background history of the Questcor business model).

At least two papers have so argued, one by Kent Bernard in this symposium and one by Greg Werden. See Kent Bernard, When the Price Isn't Right-The Lundbeck Case and the A Path to Analyze Competition in Drug Research and Development, in this issue of The Antitrust Bulletin; Gregory J. Werden, The Economics of FTC v. Lundbeck: Why Drug Mergers May Not Raise Prices, 9 J. COMPETTTION L. \& ECON. 89 (2012).

10 The drugs are not bio-equivalent-while they treat the same condition, they are actually different chemical compounds. FTC v. Lundbeck, Inc., 
(PDA). ${ }^{11}$ As PDA treatments they are equally effective, ${ }^{12}$ and at least at the time of trial there was no consensus that either was preferred. ${ }^{13} \mathrm{By}$ then, a majority of hospitals carried one but not both, with the bulk of those single-drug hospitals still preferring Indocin. ${ }^{14}$ In any event, the

No. 08-6379, 2010 WL 3810015, at *3 (finding of fact 18) (D. Minn. Aug. 31, 2010), aff'd, 650 F.3d 1236 (8th Cir. 2011). The findings of fact contained in the court's opinion will be referred to, by paragraph number, as FF. Also, the drugs are marketed under FDA labels that differ slightly. Compare FF 15 with FF 16. They also appear to differ in some ways in safety and side effects-specifically, Indocin has some impact on urine output and renal function and affects blood flow to the brain and gastrointestinal tract (FF 101)-and Indocin, unlike NeoProfen, can be used to treat a separate condition involving brain hemorrhaging (FF 15).

A lot has been made of these facts, even though there was very little evidence at the time of trial that doctors thought the differences mattered. See infra note 13. In any case, one might have thought they shouldn't matter all that much, since it is elementary that products can be in the same product market without being perfect substitutes. See United States v. E.I. du Pont de Nemours \& Co. (Cellophane), 351 U.S. 377, 394 (1956) (antitrust does not "require that products be fungible to be considered in the relevant market"). But see FF 116 (virtually the court's only fact finding directly on point, finding that "NeoProfen and Indocin IV are distinct; their side effects differ"); Bernard, supra note 9 (citing to purportedly distinguishing features, and arguing that "[a]ttempting to treat these products as fungible widgets ... was an invitation to disaster.").

$11 \quad$ FF 14.

12 FF 21 (so finding, on the basis of "[p]ublished clinical studies").

1.3 The court heard some expert testimony that the purported safety differences were either irrelevant, see FF 101 (differences "clinically insignificant"), FF 103 (neonatologist saw no "real advantages or differences"), or very minor, FF 102 (neonatologist comfortable with either drug for "vast majority" of patients), FF 105 (neonatologist comfortable with either drug if NeoProfen were unavailable). The lack of any clear demonstration of NeoProfen's purported safety benefits, and concerns about safety risks of its own, frustrated much of Lundbeck's marketing plan for the drug, as it had intended to differentiate it as the safer, superior alternative as soon as Indocin faced challenge from a generic competitor. As late as 2008-two years into the differentiation effort-Lundbeck's internal documents indicated that NeoProfen's poor sales were still explained by the company's failure to persuade hospitals that it was safer than Indocin. FF 83-84. See also Lundbeck, $650 \mathrm{~F} .3 \mathrm{~d}$ at 1240 (characterizing the evidence below as showing that "[ $t$ ] he neonatologists' preferences differed (some prescribe Indocin IV, others NeoProfen)").

14 By 2009, fifty-one percent of hospitals purchased Indocin, another fortytwo purchased both drugs, and five percent purchased only NeoProfen. FF 94. 
two drugs are challenged only by a disfavored, last-resort surgical alternative. ${ }^{15}$ Lundbeck's predecessor, Ovation, the pharmaceutical troll, bought Indocin IV from Merck in 2005, pretty clearly with the design of exploiting a big pocket of previously untapped market power. ${ }^{16}$ It correctly predicted that the initial purchase of Indocin would be profitable, despite its lack of patent protection, because getting a generic drug into production takes a while. In fact, it was much more profitable than predicted. ${ }^{17}$ And it then discovered a way to extend the payday by shortly thereafter acquiring NeoProfen, ${ }^{18}$ a drug that was even more promising

15 PDA can also be corrected by surgery, but surgery is a less desired alternative. See FF 11, 12 (finding surgery to be only a "second-line" or "rescue" treatment of PDA and significantly more expensive than drugs).

16 Specifically, the court quoted from a Lundbeck executive's analysis prepared in advance of the initial acquisition, who recommended it as "a group of medically niche small volume products that don't have substitutes and that are significantly under priced to the market. In the U.S. we can price these almost anywhere we want given the product profiles." FF 43. As mentioned, shortly after the acquisition of NeoProfen Lundbeck increased the price of Indocin by about $1400 \%$. Lundbeck also raised the prices of the four other drugs it initially acquired from Merck, by 257\%, 864\%, 979\%, and $3437 \%$, respectively. FF 57 . The district court accepted Lundbeck's contention that it would have jacked up Indocin's prices even if it hadn't acquired NeoProfen. FF 58.

17 As the court found, Ovation's internal documents laid out precisely this strategy. FF 80 (quoting a December, 2005, Lundbeck presentation to its controlling shareholder, in which it defended the plan to acquire both Indocin IV and NeoProfen) ("Our volume and sales projections for Indocin IV in the original Merck acquisition model contemplated a rapid but short-lived increase in Indocin IV sales, followed by rapidly decreasing sales over the next five years due to new competitive threats, including generic entry and [NeoProfen]."). As it happened, things went much better than that for Lundbeck-for technological reasons. Bedford Laboratories, the only manufacturer attempting to introduce indomethacin, the generic version of Indocin IV, was not able to bring a product to market until February 2010, more than four years after Lundbeck's initial price increase. See FF 57 (Lundbeck's initial price increase of Indocin IV was in January, 2006), and FF 66 (Bedford Laboratories' generic indomethacin first offered for sale in February 2010).

18 Ovation learned that Abbott was seeking FDA approval for NeoProfen less than two months before it acquired Indocin IV, and immediately after the acquisition Ovation contacted Abbott to negotiate either an acquisition of NeoProfen or an agreement to market the two drugs collaboratively. FF 33 . 
because it still enjoyed intellectual property protection. ${ }^{19}$ As long as Lundbeck's strategy to differentiate the two drugs was successful, NeoProfen could be a profitable purchase, even though it too would face some competition from generic Indocin. To us, this all seemed pretty open and shut. You benefit from a substantial period of high profits, well-protected from your only two competitive threats-generic entry, which requires a fairly long lag-time, and a therapeutic substitute nearly ready for entry, but which conveniently you've bought. You then protect the substitute through a differentiation strategy, so that once generics enter and take share from your first product, you still profit from the other. Not only would this be a rational strategy, it's what the defendant's internal documents said it was going to do.

The strangest thing about this strange case was that the court found for the defendant only after it adopted much of the findings of fact proposed by the plaintiff..$^{20}$ That surprising result was driven by its view of the institutional peculiarities of hospital drug purchasing,

19 NeoProfen enjoys patent protection until 2021, FF 16, and special "orphan drug" protection, giving its owner special, exclusive marketing rights until 2013. FF 17.

20 As a result, the court's ultimate judgment conflicted seriously with its own fact finding, and, as we argued, this should have mattered on appeal. See United States v. Cont'1 Can Co., 378 U.S. 441, 447-58 (1964) (reversing judgment as matter of law because trial court's own findings of fact did not support its market definition); FTC v. Tenet Health Care Corp., 186 F.3d 1045, 1053-55 (8th Cir. 1999) (reversing preliminary injunction because trial court's own findings of fact conflicted with its market definition); see also Morgenstern v. Wilson, 29 F.3d 1291, 1295-97 (8th Cir. 1994) (reversing permanent injunction in jury trial, where market definition was based on expert opinion but "indisputable record facts contradict or otherwise render the opinion unreasonable").

The appellate panel, however, thought it was just a fact case, despite its logical conflicts, and so affirmed solely on the standard of review. FTC v. Lundbeck, Inc., 650 F.3d 1236, 1243 (8th Cir. 2011)(affirming, because the question "[w]hether this court would come to the same conclusion" would be "irrelevant."). One member of the panel, a district judge from Nebraska sitting by designation, threw the FTC the bone of a concurrence finding the approach to market definition "perplexing," "odd," inappropriately based on testimony of doctors who "had no responsibility to pay for the drugs or otherwise concern themselves with cost," and "especially strange" in light of evidence that "(1) both drugs are effective ... and (2) internal records from the defendant raise an odor of predation." Id. at 1243 (Kopf, J., concurring). Nevertheless, like his colleagues, Judge Kopf felt that "the standard of review carries the day." Id. 
which it based on the testimony of several doctors and pharmacists to the effect that they don't consider cost when deciding which drug to use. ${ }^{21}$ We'll come back to that below. ${ }^{22}$

Another strange thing was the court's explanation of the purpose and method of its "market definition." The two kinds of evidence usually used to exclude substitutes from a relevant market-evidence disproving functional interchangeability and cross-price elasticity-were unavailable here. The evidence showed that the drugs were interchangeable for antitrust purposes. They were equally effective, and while some doctors and pharmacists expressed preferences, several also expressed indifference or a preference for Indocin only because of its longer track record. ${ }^{23}$ And you literally can't measure cross-price elasticity between two products that are offered at the same, unchanging price, especially where they are sold by the same monopolist. ${ }^{24}$ The only directly relevant evidence, of a kind normally not even admissible, was the speculation of one economic consultant hired by the defense. ${ }^{25}$

\section{CONTINENTAL CAN AND LUINDBECK CANNOT BOTH BE THE LAW}

Wholly apart from any price effects, Lundbeck's acquisition of NeoProfen caused consumer losses by way of restrained quality competition. That fact was demonstrated in the court's findings but rendered legally irrelevant by its insistence on cross-price elasticity. "Lundbeck stopped actively promoting Indocin IV," the court found, and "instructed its sales representatives to focus on Indocin IV's weaknesses relative to NeoProfen's anticipated benefits." ${ }^{26}$ This reduction and skewing of information was a clear loss to hospitals, doctors, and patients, and harmed the competitive process. ${ }^{27}$ Had Lundbeck not

\footnotetext{
${ }^{21} \quad$ See FF 94-108.

${ }^{22}$ See infra part IV.

23 See supra note 13.

24 See infra notes 48-54 and accompanying text.

25 See infra notes $44-47$ and accompanying text.

26 FF 81 .

27 Contrary to the contention of some commentators that price competition. was the only issue in the case, Werden, supra note 9, at 95, the FTC did argue nomprice effects in the district court. See Post Trial Brief of Plaintiffs at 14, FTC v.
} 
acquired NeoProfen, it would have had the incentive not only to promote Indocin IV's benefits and to challenge the claims made for NeoProfen, but also to fund research to aid the effort. ${ }^{28}$ Moreover, a separate owner of either of the drugs would strive to respond to quality competition with technological innovation and quality improvements. Lundbeck implicitly rejected these values as having any relevance to antitrust at all, by way of its insistence on "crossprice elasticity," ${ }^{29}$ and that was an error of textbook law. ${ }^{30}$ The

Lundbeck, Inc., No. 08-6379 (D. Minn. Jan. 29, 2010), 2010 WL 1229950; see also Brief for Plaintiffs-Appellants at 16, 32, 49, FTC v. Lundbeck, Inc., 650 F.3d 1236 (8th Cir. 2011) (No. 10-3458), 2010 WL 5558180 (arguing that district court erroneously ignored nonprice competition). To be sure, the issue was not central to the FTC's case, presumably because it did not support the FTC's efforts to obtain disgorgement, and the courts did not address the relevance of nonprice competition.

${ }^{28}$ Lundbeck suggested that it had no incentive to invest in efforts to promote Indocin IV because it expected rapid entry of generic indomethacin. See Defendant Lundbeck Inc.'s Reply to Plaintiffs' Post Trial Br. at 38-39, FTC v. Lundbeck, Inc., No. 08-6379 (D. Minn. Feb. 19, 2010), 2010 WL 2061874; see also Bernard, supra note 9. However, the anticipation of generic entry would not reduce returns to promotional investments to zero. Indeed, even after a drug goes generic, it is not always the case that investment in the drug by the brand falls to zero.

${ }_{29}$ FTC v. Lundbeck, Inc., No. 08-6379, 2010 WL 3810015, at *19-21 (D. Minn. Aug. 31, 2010); see also FTC v. Lundbeck, Inc., 650 F.3d 1236, 1240 (8th Cir. 2011) (citing H.J., Inc. v. Int'l Tel. \& Tel. Corp., 867 F.2d 1531 (8th Cir. 1989) for the proposition that "cross-price elasticity is essential to market definition").

30 It is well settled that restraints on quality or other nonprice competition may be unlawful and sometimes are summarily condemned. See, e.g., FTC v. Ind. Fed'n of Dentists, 476 U.S. 447, 459-60 (1986) ("refusal to compete with respect to the package of services offered to customers, no less than a refusal to compete with respect to the price term of an agreement, impairs the ability of the market to advance social welfare" ); 2010 HORIZONTAL MERGER GUIDELINES, supra note 6, § 1 ("Enhanced market power can also be manifested in non-price terms and conditions that adversely affect customers, including reduced product quality, reduced product variety, reduced service, or diminished innovation. Such nonprice effects may coexist with price effects, or can arise in their absence."); id. $\S$ 4.1 .2 (noting that the focus on "small but significant and non-transitory" price changes, "is used because normally it is possible to quantify [such changes,] not because price effects are more important than non-price effects."); id. $\$ 4$ (demand substitution considers whether customers will substitute away from one product to another "in response to a price increase or a corresponding non-price change, such as a reduction in product quality or service"). 
Supreme Court's leading decision on point, United States v. Continental $\mathrm{Can}_{r}{ }^{31}$ found that glass and metal containers were in the same relevant market, despite a lack of cross-price elasticity. The district court's finding of separate markets, said the Continental Can majority, "employed an unduly narrow construction of the 'competition' protected by $\S 7 . "{ }^{32}$ Lack of price effects is "relevant . . . but not determinative," ${ }^{\prime 3}$ because while rivalry on quality terms "may not be price competition[] . . . it is nevertheless meaningful competition between interchangeable containers. ${ }^{.34}$ It is competition "of the type and quality deserving of $\S 7$ protection and therefore the basis for defining a relevant product market." ${ }^{35}$ In short, Continental Can makes clear that because the antitrust laws protect nonprice competition as well as price competition, functionally interchangeable economic substitutes can be in the same relevant market even when consumers are not price sensitive. ${ }^{36}$

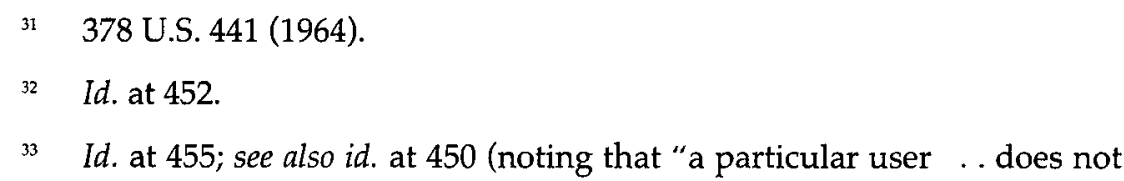
shift back and forth from day to day as price and other factors might make desirable").

id. at 456.

35 Id. at 449; see also, e.g., FTC v. Tenet Health Care Corp., 186 F.3d 1045, 1054 (8th Cir. 1999) ("The district court placed an inordinate emphasis on price competition without considering the impact of a corresponding reduction in quality.").

36 See Petition for Rehearing en Banc of Plaintiffs-Appellants at 11, FTC v. Lundbeck, Inc., 650 F.3d 1236, 1240 (8th Cir. 2011) (No. 10-3458) ("'the outer boundaries of a product market are determined by the reasonable interchangeability of use or the cross-elasticity of demand between the product itself and substitutes for it"' (quoting Brown Shoe Co., Inc. v. United States, 370 U.S. 294, 325 (1962) (emphasis added by FTC))). Of course, reasonable interchangeability of use is not always an appropriate metric, and drugs that are therapeutic substitutes may be in separate product markets in a merger combining a brand drug with its generic substitute. As the Supreme Court explained in Continental Can, "Since the purpose of delineating a line of commerce is to provide an adequate basis for measuring the effects of a given acquisition, its contours must, as nearly as possible, conform to competitive reality." 378 U.S. at 457. 
Lundbeck's most perverse consequence is that it is precisely those markets lacking price competition that need nonprice rivalry the most. Moreover, to the extent that Lundbeck is taken to require a showing of significant cross-price elasticity in order for two products to be in the same relevant market, it has potentially far-reaching consequences in other markets where competition primarily occurs on nonprice attributes, including a fair portion of the health care sector and consumer markets for free Internet or media services. Indeed, a cross-price elasticity requirement may not only immunize mergers in price-insensitive markets, but the logic would seem to allow naked horizontal restraints (such as market allocation agreements) in such markets on the ground that the conspirators are not horizontal competitors at all because their products are not in the same relevant market.

\section{OH, AND BY THE WAY, ARE WE REALLY SO SURE THERE WAS NO PRICE COMPETITION? SERIOUSLY?}

But let us assume, contrary to theory, evidence, and law, that nonprice competition is irrelevant. Here, the proof still showed pretty overwhelmingly that these drugs would constrain one another's prices. First, a serious problem was the court's method for testing cross-price elasticity, in that the facts chosen to test it really just can't be used as they were here. But that is all fairly academic in comparison to the second problem, which was that the court's own findings overwhelmingly showed that these two drugs actually were pricecompetitive, in a way protected by antitrust.

\section{A. Methodology: The trial court's "test" of cross-price elasticity}

Lundbeck is a living testament that the plural of anecdote is not data. Admittedly, it rested on the testimony of a large absolute number of people, as these things go, and that fact seemed important to the court. Specifically, thirteen people-seven doctors, ${ }^{37}$ four pharmacists, ${ }^{38}$

37 FF 102-08.

${ }^{38}$ FF 96, 97, 99, 100. The court also heard from the chair of the Department of Pharmaceutical Care and Health Systems at the University of Minnesota who said hospitals do care about prices and that hospitals could use purchasing decisions to force prices down. Without explanation, the court rejected that testimony as "unpersuasive." FF 95. 
and two economists ${ }^{39}$-essentially said that prices didn't really matter. But even aside from general doubts as to forward-looking consumer testimony, ${ }^{40}$ the fact that the court relied on customer witnesses who don't actually pay for the products, and the fact that they were not asked the right questions, ${ }^{41}$ there was a serious problem in the inference the court drew from their testimony. A court relying on a small sample of customer opinion discovers no more than the earth-shattering fact that some consumers are inframarginal. It takes only some marginal consumers to make price competition work. In fact, real-world markets are common in which large numbers of consumers are inframarginal to the profit-maximizing price of a differentiated good. That is to say, in any market except a highly competitive one, it would not be uncommon for a defendant to find that plenty of its customers would not switch away from the product, even if price were raised above the monopoly price. ${ }^{42}$ Most antitrust courts understand this fact. ${ }^{43}$

39. FF 95, 115.

40 See 2B AREEDA \& HOVENKAMP, supra note 5, at II 538b (arguing that forward-looking consumer testimony generally should be disfavored in market definition); Sean P. Gates, Is the Customer Never Right? Bazaarvoice and Customer Testimony in Merger Litigation, ANTITRUST, Spring 2014, at 61 (discussing evolving case law concerning customer testimony).

${ }^{41}$ Even assuming, as the court stressed, that no doctors would be swayed by a twenty percent discount, see FF 97, 104, 105, 106, 108, some might well switch if the price were reduced by thirty percent, or if, for example, Indocin IV jumped from $\$ 108.88$ to $\$ 1500$ (as it did), and NeoProfen had been priced at $\$ 450-\$ 500$ (at which Abbott had originally intended to sell it, see FF 61). Moreover, the question some of these witnesses answered was whether they would prescribe a less safe drug, whereas it had not been shown at all that NeoProfen was less safe. See supra note 13.

4i As Hovenkamp observes, in any product-differentiated market, especially where price-cost margins are already high (as they were here), it will be common for many inframarginal consumers to have willingness-to-pay above monopoly price. Hovenkamp, supra note 4 , at $2 \&$ n. 10 .

${ }^{43}$ See United States v. Engelhard Corp., 126 F.3d 1302, 1306 (11th Cir. 1997) (" $\mathrm{I}] \mathrm{t}$ is possible for only a few customers who switch to alternatives to make [a] price increase unprofitable, thereby protecting a larger number of customers who would have acquiesced in higher ... prices."). 
The court's finding also depended in part on the informal opinion of one economic consultant, ${ }^{44}$ who opined on elasticity during his live testimony ${ }^{15}$ but admitted that he had done no statistical or econometric analysis of any evidence. ${ }^{46} \mathrm{He}$ was nonetheless willing to answer that elasticity was "very low." Aside from the fact that other courts have held that kind of speculation not even admissible, ${ }^{47}$ an actual estimate would have been impossible. In its technical sense, ${ }^{48}$ cross-price elasticity is estimated in antitrust litigation by statistical analysis of price changes over time, requiring data on the behavior of the two products when the price of one of them changes. ${ }^{49}$ But given their lack of price variation, such a procedure would have been impossible in

${ }^{H}$ FF 115. Even though the court found as a fact that cross-price elasticity is "very low," FF 116, the court may have meant to imply that its ultimate finding rested merely on plaintiffs' burden of proof. According to the court, plaintiffs' economic expert did not offer an opinion as to cross-elasticity. FF 114; cf. FF 111. Yet, in its denial of Lundbeck's motion for summary judgment, the district court recognized that even the total absence of cross-elasticity evidence does not preclude a finding in favor of plaintiffs' proposed market. FTC v. Lundbeck, Inc., No. 08-6379, 2009 WL 2215006, at *2 n.2 (D. Minn., July 21, 2009). Moreover, if the failure of proof were the court's rationale, it would be error because, as we will explain, it would be literally impossible in this case for either party accurately to estimate cross-elasticity.

$45 \quad$ FF 115.

46 According to the court, the expert "did not calculate a specific crossprice elasticity between NeoProfen and Indocin IV, [but] he testified that that it is very low." Id. Even on Lundbeck's characterization of his testimony, the most he did was speculate on the basis of his perception of an institutional market failure. Defendant's Post Trial Brief at 4-5, FTC v. Lundbeck, Inc., No. 08-6379 (D. Minn. Feb. 19, 2010), 2010 WL 2061873.

47 See, e.g., McLaughlin Equip. Co. v. Servaas, No. 98-127, 2004 WL 1629603, at *6 (S.D. Ind. Feb. 18, 2004) ("It is insufficient for an expert to merely mention cross-elasticity of demand or supply; an analysis is required.").

48 Economists define cross-price elasticity as the percentage change in the quantity demanded for a product associated with each one-percent change in the price of another product. See 2B AREEDA \& HOVENKAMP, supra note 5 , at II 507a.

49 See Am. BAR Ass'N, SEction of Antitrust L., Econometrics: LeGAL, PRACTICAL, AND TECHNICAL Issues 269-309 (2005); Andrew M. Rosenfeld, The Use of Economics in Antitrust Litigation and Counseling, 1986 ColUM. Bus. L. REV. 49, 63-67. 
Lundbeck. ${ }^{50}$ Moreover, during the entire short period of their "competition," NeoProfen and Indocin IV were both owned by the same monopolist.

The elasticity finding in Lundbeck, in other words, was the Cellophane fallacy on steroids. Just as high cross price elasticity at monopoly prices is irrelevant, ${ }^{\text {,1 }}$ seeming lack of it between two products sold by the same monopolist is as well. ${ }^{52}$ (And, we should recall, under black letter law monopolists should enjoy no inferences from facts in their own control. ${ }^{53}$ ) Indeed, if the benchmark price for Indocin were the monopoly price, as Lundbeck claimed, then stan-

so There was no variation in price during the entire time that both products were available. Prior to July 2006, only Indocin IV was available, and by that time Lundbeck had already raised its price to $\$ 1500$ per three-vial course of treatment. FF 57. When Lundbeck introduced NeoProfen in July 2006, it offered the drug at $\$ 1450$ per three-vial course of treatment (raising it to $\$ 1552.50$ about one year later). FF 62. As some courts have understood, crosselasticity cannot be measured without price variation. See Nobody in Particular Presents, Inc. v. Clear Channel Commc'ns, Inc., 311 F. Supp. 2d 1048, 1082 (D. Colo. 2004).

51 See Am. Bar Ass'n, Sect. of Antitrust L., Market Power Handbook 59-60 (2005) (describing the Cellophane fallacy); see also Eastman Kodak Co. v. Image Technical Servs., Inc., 504 U.S. 451, 471 (1992) ("The existence of significant substitution in the event of further price increases or even at the current price does not tell us whether the defendant already exercises significant market power.").

52 It is elementary that the significance of price elasticity evidence depends on the benchmark price against which it is measured, as well as the price of substitute products. See 2010 MERGER GUIDELINES, supra note 6; Steven C. Salop, The First Principles Approach to Antitrust, Kodak and Antitrust at the Millennium, 68 ANTITRUST L.J. 187 (2000).

53 See United States v. Microsoft Corp., 253 F.3d 34, 79 (D.C. Cir. 2001) ("To require that $\S 2$ liability turn on a plaintiff's ability or inability to reconstruct the hypothetical marketplace absent a defendant's anticompetitive conduct would only encourage monopolists to take more and earlier anticompetitive action."); United States v. Aluminum Co. of Am., 148 F.2d 416, 424-25 (2d Cir. 1945) (excluding "secondary" aluminum ingot from defendant Alcoa's market because Alcoa had some control over how much secondary market there could be). 
dard market-definition analysis would require that the next-best substitute (NeoProfen) be included in the relevant market. ${ }^{54}$

\section{B. Contrary fact findings, and some deeply suspicious conduct}

But in any case, as we said, what was really strange in Lundbeck was the demonstration of price competition that ran throughout the court's findings of fact. Oddly, a number of findings just explicitly state that the drugs are price-competitive substitutes. "When launching NeoProfen," said the court, "an independent owner would not have disregarded Indocin IV's price." ${ }^{55}$ The court also found that in Lundbeck's internal strategic analyses, it perceived the two drugs to be in direct price competition. ${ }^{56}$ Lundbeck perceived that, no doubt, because clinical evidence showed them to be equally effective for their FDA-approved use ${ }^{57}$ and because, despite the preferences of some doctors and pharmacists, the general feeling in the medical community seemed to be pretty equivocal between them. ${ }^{58}$ There also was the fact that in projecting the initial price for Indocin, before it was even aware that NeoProfen was in development, Lundbeck took into consideration the much higher cost of surgical treatment for PDA, and then lowered the projected price when it learned of NeoProfen. ${ }^{59}$

54 See FTC \& U.S. DeP'T OF JUSTICE, HorizOnTAL MERGER Guidelines § 1.11 (1992) (once hypothetical monopolist finds it unprofitable to raise prices, next-best substitute is added to the relevant market).

55 $\quad$ FF 63.

56 See FF 79 (combining the two products was expected to "allow us to cannibalize our Indocin IV sales in a controlled manner . and continue to grow total company sales in the PDA market"); FF 80 (combination would "allow Lundbeck to realize a more stable revenue stream for both products within the PDA market"); FF 82 (NeoProfen introduced with a three percent discount to Indocin IV to "take[] away potential pharmaeconomic debate"); FF 84 (reasons that some customers were not ordering NeoProfen included price).

57 FF 21 (finding clinical evidence to show both drugs equally effective at treating $\mathrm{PDA})$.

58 See supra note 13.

59 FF 44,45 
The court's view that "neonatologists are the relevant consumers" is also dubious. Its own findings show that hospitals are price sensitive and make the actual purchase decisions, ${ }^{61}$ and that some hospitals would be in a position to seek lower prices..$^{62}$ The court of appeals affirmed those findings in a stark, matter-of-fact summary: "Hospitals use inclusion in the formulary to extract better prices from sellers of clinically-substitutable drugs. ${ }^{\prime 63}$ If only doctors' opinions mattered, it would be hard to explain Lundbeck's outreach to nonphysician members of hospital pharmacy and therapeutics committees. ${ }^{64}$ And if only quality was relevant, it would be hard to explain its price incentives. ${ }^{65}$ It would also be hard to explain the fact that insurers and other purchasers exert efforts to steer doctors toward cheaper alternative drugs when they can. ${ }^{66}$ If it wouldn't work, why bother? And if it does, then even drugs administered only in hospitals are subject to price constraints entitled to antitrust protection.

Likewise, on the court's findings, a range of Lundbeck's conduct would have been irrational unless Lundbeck itself thought the drugs were substitutes. Antitrust usually applies a strong presump-

$60 \quad$ FF 113.

61 FF 88 .

62 FF 93 ("Hospitals may try to control costs within their formularies. When two or more sellers of clinically substitutable drugs vie for inclusion on a formulary, a hospital may use its formulary system to negotiate price concessions by promising or threatening to use more or less of a drug.").

63 FTC v. Lundbeck, Inc., 650 F.3d 1236, 1238 (8th Cir. 2011).

64 FF 83, 85.

65 When Lundbeck first introduced NeoProfen in 2006, it keyed NeoProfen's price to the price of its existing Indocin product, minus a three percent discount, to "allow[] [sales] rep[resentatives] to spend more time selling product differentiation in the NICU vs. spending time with the pharmacy director on price...." FF 82. See also id. (also noting that small discount "will not convert the economic driven vial splitting crowd").

66 Hovenkamp, supra note 4, at 3 n.12. Bernard draws the interesting (though unsupported) distinction that insurers mostly do this with respect to drugs for long-term use, and not acute care, single-use drugs like Indocin and Neoprofen. Bernard, supra note 9. The court made no such finding, however, and in any case there was plenty of other evidence of price sensitivity. 
tion of rationality, ${ }^{67}$ so this should have been evidence of meaningful competition.

Immediately after acquiring the two products, Lundbeck began an effort to differentiate them on the basis of safety and side effects, an effort comprising several million dollars invested in direct marketing efforts. ${ }^{68} \mathrm{~A}$ strategy to "accelerate the conversion of first-line PDA treatment from Indocin IV to [NeoProfen]" ${ }^{\prime 69}$ would make no sense if the products were not substitutes. For one thing, if the products were not substitutable, a rational firm would not waste money trying to convince consumers that they differ. If Indocin and Neoprofen really were not substitutable, then consumers should not have needed millions of dollars' worth of convincing of it.

But more importantly, if the drugs were not substitutes, the differentiation strategy would be self-defeating. Lundbeck was the owner of two separate products, which it acquired for tens of millions of dollars. Absent other explanation, its rational strategy would be to maximize the profits from each of them. But on the contrary, after spending significant sums to acquire two separate drugs to treat the same condition, within six months of one another, it then devoted itself to disparaging one of them to its consumers. ${ }^{70}$ It would be peculiar indeed for the supplier of two separate, noncompeting products to discourage sales of either. In this case Lundbeck not only did that, but apparently sought to kill off demand for one of them altogether.

67 That was the law in the Eighth Circuit, e.g., FTC v. Tenet Health Care Corp., 186 F.3d 1045, 1054 (8th Cir. 1999) (a finding of behavior "contrary to [the actor's] economic interests . is suspect"), and elsewhere, because "antitrust law limits the range of permissible inferences from ambiguous evidence," Matsushita Elec. Indus. Co., Ltd. v. Zenith Radio Corp., 475 U.S. 574, 588 (1986) (holding that where evidence of antitrust defendant's conduct is ambiguous, courts presumptively construe it in way most consistent with rational behavior).

${ }_{68}$ Lundbeck established a massive, direct-sales marketing effort involving dozens of its own sales personnel and scores more from Abbott Laboratories (for which Lundbeck paid $\$ 2$ million) to convince customers of NeoProfen's superiority. FF 34, 81-87.

$69 \mathrm{FF}$ at 80.

$70 \quad$ FF 81. 
By contrast, all of this behavior is nicely explained under the simple alternate story that we already laid out above. The differentiation strategy makes sense if the products in fact were good substitutes, because Indocin would shortly face serious challenge from a generic substitute. ${ }^{71}$ It was therefore crucial to Lundbeck to differentiate them in order to protect NeoProfen's intellectual property-protected profit potential from the generic competition that would overtake Indocin. ${ }^{72}$ As the court itself found, Lundbeck sought to convert Indocin users to NeoProfen because it expected generic competition to Indocin, which would take more sales away from Indocin than from NeoProfen. ${ }^{73}$

Along these lines, one concluding statement in the Lundbeck opinion, apparently meant as sort of a Q.E.D. moment, actually captured just how poorly the court understood what happened in this case: "Were NeoProfen and Indocin IV in the same product market, Lundbeck's attempt to persuade neonatologists to switch from Indocin IV to NeoProfen would not make sense." ${ }^{\prime 74}$

On the contrary, it is the only thing that makes sense.

In any case, other firms in the sector also thought the drugs were substitutes. The court found that, though Lundbeck always intended to increase the price of Indocin after its acquisition, it deliberately chose not to do so until after it had completed negotiations with Abbott Laboratories for the acquisition of NeoProfen: "Lundbeck was concerned that Abbott Laboratories would demand a higher price for the rights to NeoProfen if the announcement of Indocin IV's price increase took place before Lundbeck's acquisition of the rights to NeoProfen." ${ }^{\prime 75}$ But why would Abbott do any such thing if the two products were not price competitors? Likewise, while Abbott wanted to introduce NeoProfen at a much higher price than Indocin, ${ }^{76}$ that plan

71 See supra note 17 and accompanying text.

72 See supra note 28 and accompanying text.

73 FF 64.

74 FF 116.

$75 \quad$ FF 58.

$76 \quad$ FF 61. 
depended on FDA approval of a label stating NeoProfen's superiority to it. When the agency rejected the label, ${ }^{7}$ Abbott gave up and sold the drug to the one firm that could price both of them without fear of competition. Moreover, even when Abbott was planning that higher price, it projected only $\$ 450$ to $\$ 500$ per treatment, because at that time Merck still owned Indocin and was selling it for less than $\$ 80 .^{78}$

\section{A FEW FINAL THOUGHTS ON TYPE I VS. TYPE II BALANCE, OR, I MEAN, SERIOUSLY GUYS, COME ON}

But finally, none of the foregoing is really as important to us as one much more general point of policy. Some writers on Lundbeck appear intent on trying to support the court's holding by emphasizing certain facts ${ }^{79}$ or abstruse theoretical possibilities, ${ }^{80}$ but in doing so they beg a very big question. There is a reason that we do not always force plaintiffs into complex and expensive fact litigation or make them overcome every conceivably plausible defense theory. We do in fact care about false negative risk, even though this somehow came to be dwarfed by fear of false positives (despite the lack of empirical evidence one way or the other ${ }^{81}$ ). We also care about the message that is sent by excessive cost or complexity hurdles to enforcement. Clear

$7 \quad$ FF $16,36,61$.

78 FF 61.

79 For example, Bernard, supra note 9, is mostly devoted to identifying drug industry facts purportedly rendering price competition unlikely (contrary to much of the evidence and the trial court's findings).

${ }^{80}$ Werden, supra note 9, defends the Lundbeck result by postulating a model showing that "competition can produce monopoly pricing." Id. at 93. Dr. Werden assumes rather a big can opener, by taking all the court's fact finding as true, including the finding that there is little cross price-elasticity; he then asks if the market would be competitive. It is possibly not so earth shattering that if your model assumes no price competition, then it will predict that there won't be any price competition. Nonetheless, Werden does not suggest that the two drugs are in different product markets.

${ }^{81}$ See generally John E. Kwoka, Jr., The Attack on Antitrust Policy and Consumer Welfare: A Response to Crandall and Winston 2-3 (Northeastern Univ. Dep't of Econ. Working Paper 03-008, June 2003) (noting absence of empirical evidence on the effects of enforcement error). 
rules aid private ordering, ${ }^{82}$ but more importantly signal to business that antisocial risks aren't worth taking. Had the Commission won in Lundbeck, for example, we might not have had to deal with that other pending drug acquisition mentioned above, which has resulted in a $56,000 \%$ price increase. ${ }^{83}$

For these reasons, antitrust deliberately generalizes a simple set of rules across most markets, and limits the kinds of arguments one can make to avoid them (or at least it used to), but not because anyone really knows for sure how well price theory accurately captures most markets. This sort of thing shouldn't be surprising to anyone in the drug sector or elsewhere, because the Supreme Court has been saying it for decades. For example, you can't say you need trade-restraining professional association rules to prevent unsafe workmanship, because:

[ $t$ ] he assumption that competition is the best method of allocating resources in a free market recognizes that all elements of a bargain-quality, service, safety, and durability - and not just the immediate cost, are favorably affected by the free opportunity to select among alternative offers. ${ }^{84}$

For the same reason, you can't argue that your market-restraining conduct is needed to conserve natural resources, ${ }^{85}$ or to address instability or overcapacity, ${ }^{86}$ or to prevent any other sort of "ruinous" or "destructive" competition. ${ }^{87}$ It is for these reasons that, in the merger con-

82 United States v. Phila. Nat'1 Bank, 374 U.S. 321, 362 (1963) ("unless businessmen can assess the legal consequences of a merger with some confidence, sound business planning is retarded.").

83 See supra note 8 and accompanying text.

84 Nat'l Soc'y of Prof'l Eng'rs v. United States, 435 U.S. 679, 692 (1978).

${ }_{85}$ Cf. United States v. Socony-Vacuum Oil Co., 310 U.S. 150, 170 (1940) (noting evidence that vigorous competition might cause some oil wells to be abandoned and the oil within them to be lost, but finding price-fixing conspiracy illegal nonetheless).

86 Cf. id. at 171-72 (discussing conditions of acute overcapacity, which also were held legally irrelevant).

87 See Atl. Richfield Co. v. USA Petroleum Co., 495 U.S. 328, 338 \& n.7 (1990)("a firm cannot claim antitrust injury from nonpredatory price competition on the asserted ground that it is 'ruinous' " (citing United States v. Topco Assocs., Inc., 405 U.S. 596, 610-12 (1972))); Phila. Nat'l Bank, 374 U.S. at 371 
text, antitrust is supposed to contain an "incipiency" presumption, ${ }^{88}$ and why we usually see a rule of effectively per se illegality for monopoly-preserving mergers. ${ }^{89}$ The whole purpose of these rules is to free enforcement from abstruse, opaque theoretical fantasies and expensive factual litigation.

And so our question about Lundbeck, in the end, is not whether there is some plausible scenario in which the challenged conduct does not make a bad competitive situation worse. The question is, so what? Why shouldn't a monopolist's acquisition of its next closest competitor promising literally no social benefit, and which can be identified as such relatively easily, be illegal?

(conduct challenged in antitrust "is not saved because, on some ultimate reckoning of social or economic debits and credits, it may be deemed beneficial. A value choice of such magnitude is beyond the ordinary limits of judicial competence, and in any event has been made for us already, by Congress when it enacted [the antitrust laws]."); Socony-Vacuum, 310 U.S. at 222 ("Whatever may be its peculiar problems and characteristics, the Sherman Act, so far as price-fixing agreements are concerned, establishes one uniform rule applicable to all industries alike.").

88 Phila. Nat'l Bank, 374 U.S. at 362 (Clayton Act section 7 "was intended to arrest anticompetitive tendencies in their 'incipiency.' ").

89 See supra note 5 .

so See, e.g., Derek C. Bok, Section 7 of the Clayton Act and the Merging of Law and Economics, 74 HARV. L. Rev. 226 (1960); Herbert Hovenkamp, Derek Bok and the Merger of Law and Economics, 21 U. Mich. J.L. ReForm 515 (1988). 


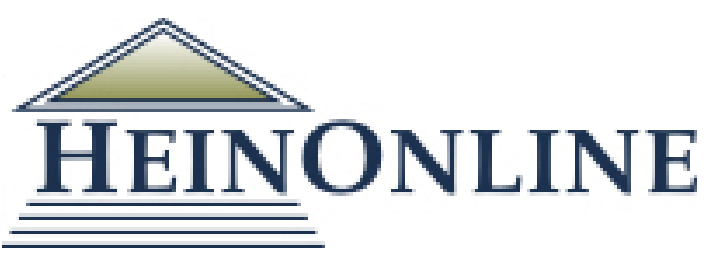

Content downloaded/printed from

HeinOnline

Tue Oct 15 11:40:46 2019

Citations:

Bluebook 20th ed.

Chris Sagers; Richard M. Brunell, FTC v. Lundbeck: Is Anything in Antitrust Obvious, Like, Ever, 59 Antitrust Bull. 557 (2014).

ALWD 6th ed.

Chris Sagers; Richard M. Brunell, FTC v. Lundbeck: Is Anything in Antitrust Obvious, Like, Ever, 59 Antitrust Bull. 557 (2014).

APA 6th ed.

Sagers, C.; Brunell, R. M. (2014). Ftc v. lundbeck: Is anything in antitrust obvious, like, ever. Antitrust Bulletin, 59(3), 557-578.

Chicago 7th ed.

Chris Sagers; Richard M. Brunell, "FTC v. Lundbeck: Is Anything in Antitrust Obvious, Like, Ever," Antitrust Bulletin 59, no. 3 (Fall 2014): 557-578

McGill Guide 9th ed.

Chris Sagers \& Richard M Brunell, "FTC v. Lundbeck: Is Anything in Antitrust Obvious, Like, Ever" (2014) 59:3 Antitrust Bull 557.

MLA 8th ed.

Sagers, Chris, and Richard M. Brunell. "FTC v. Lundbeck: Is Anything in Antitrust Obvious, Like, Ever." Antitrust Bulletin, vol. 59, no. 3, Fall 2014, p. 557-578.

HeinOnline.

OSCOLA 4th ed.

Chris Sagers and Richard M Brunell, 'FTC v. Lundbeck: Is Anything in Antitrust

Obvious, Like, Ever' (2014) 59 Antitrust Bull 557

Provided by:

Cleveland-Marshall College of Law Library

-- Your use of this HeinOnline PDF indicates your acceptance of HeinOnline's Terms and Conditions of the license agreement available at https://heinonline.org/HOL/License

-- The search text of this PDF is generated from uncorrected OCR text.

-- To obtain permission to use this article beyond the scope of your license, please use: Copyright Information

Use QR Code reader to send PDF to your smartphone or tablet device

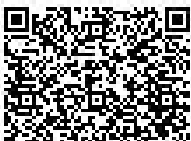

